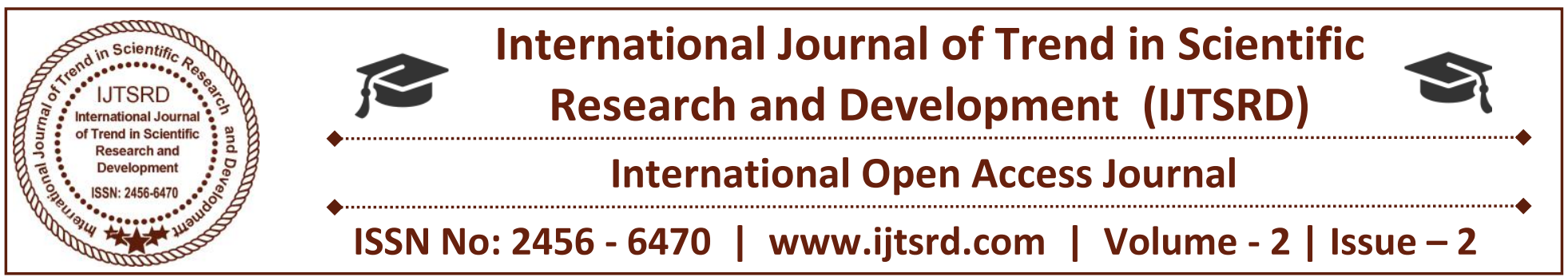

\title{
Indian Banking Sector and Micro Finance
}

\author{
Rajendra Prakash Agrawal \\ Reseach Scholar, \\ Monad University, Uttar Pradesh
}

\author{
A. H. Khan \\ Associate Professor, School of \\ Management and Business Studies, \\ Monad University, Uttar Pradesh
}

\section{ABSTRACT}

Indian banking system is fully mature and based on the best practices of world banking. In last decay world economy see many up and down but our banking sector does not affect negatively and in fact after recession of 2007-08 our banking system makes necessary some modification. So that system can face any eventuality in future. After 1991 Indian economy open up and think beyond protected walls and do what other developing countries are doing but with great care of our environment and capability.

As the most of the rural population is still not using formal banking system so they are not aware abut micro finance instrument that is why they are not included in the inclusive growth story of India. The concept of financial inclusion becomes quite challenging for the Indian rural economy. Since 2006, many focused initiatives are taken by NABARD and Government of India in favor of financial inclusion but the impact of these did not result satisfactory outcome. The paper aims to focus on using the existing resources such as Mobile and smart phones, Banking Apps, Indian Post Office, Internet banking and Non banking financial institutions (NBFCs) thereby making it more healthy and user friendly for the interest of the rural population as well as the formal sector. My study focused on 250 students studying in Monad University and most of student are lacking in basic financial literacy. So knowing the facts behind backwardness in rural population of different part of India .we frame questionnaire and use simple statistical tools and analyze the problem and found that most of Government and private schemes related to financial inclusion( crop insurance, Beema youjna.jandhan account, sukanyia, rural mutual funds,kisan vikas patra) are not properly convinced to the masses. Usually government official goes to rural areas and hold a formal talk in difficult language and so on. For making them aware about financial instrument we can use SMS service in local languages. What my study found that they have enough money but in absence financial literacy they are putting into debt instruments which are not yielding enough to beat inflation. Their saving can be channelize into well diversified mutual by way of SIP

Keywords: Financial inclusion, Business correspondents, Micro finance schemes Indian Economy

\section{INTRODUCTION}

We start our journey of economic development of India since post independence With Hindu growth rate $3.5 \%$ to 8.9 in $2007-08$ and on average $7.5 \%$ from last 25 years change the profile of India the progress of the Indian economy, especially when the focus is on upliftment of people living at the bottom of premed is proved as sustainable development., There must be an attempt to include maximum number of participation from all the sections of the society from all part of country. The attempt had been made in 1969 by Nationalization of dozen of banks in single go But the lack of awareness and financial literacy among the rural and same urban population of the country .This big attempt (Nationalization of banks) not result to include everybody in formal banking system so lowering the growth of the economy as majority of the population does not have access to formal credit as world bank report only 35\% 
population have bank account. This is a serious issue for the economic progress of the country. In order to overcome such barriers, the banking sector emerged with some technological innovations such as automated teller machines (ATMs), credit and rupee cards, internet banking (only 34\% have internet connectivity), etc. Though introduction of such banking cutting edge technologies brought a change in the urban society, a lot of the rural population is still unaware of these innovations of banking technology and is out of formal banking channel.

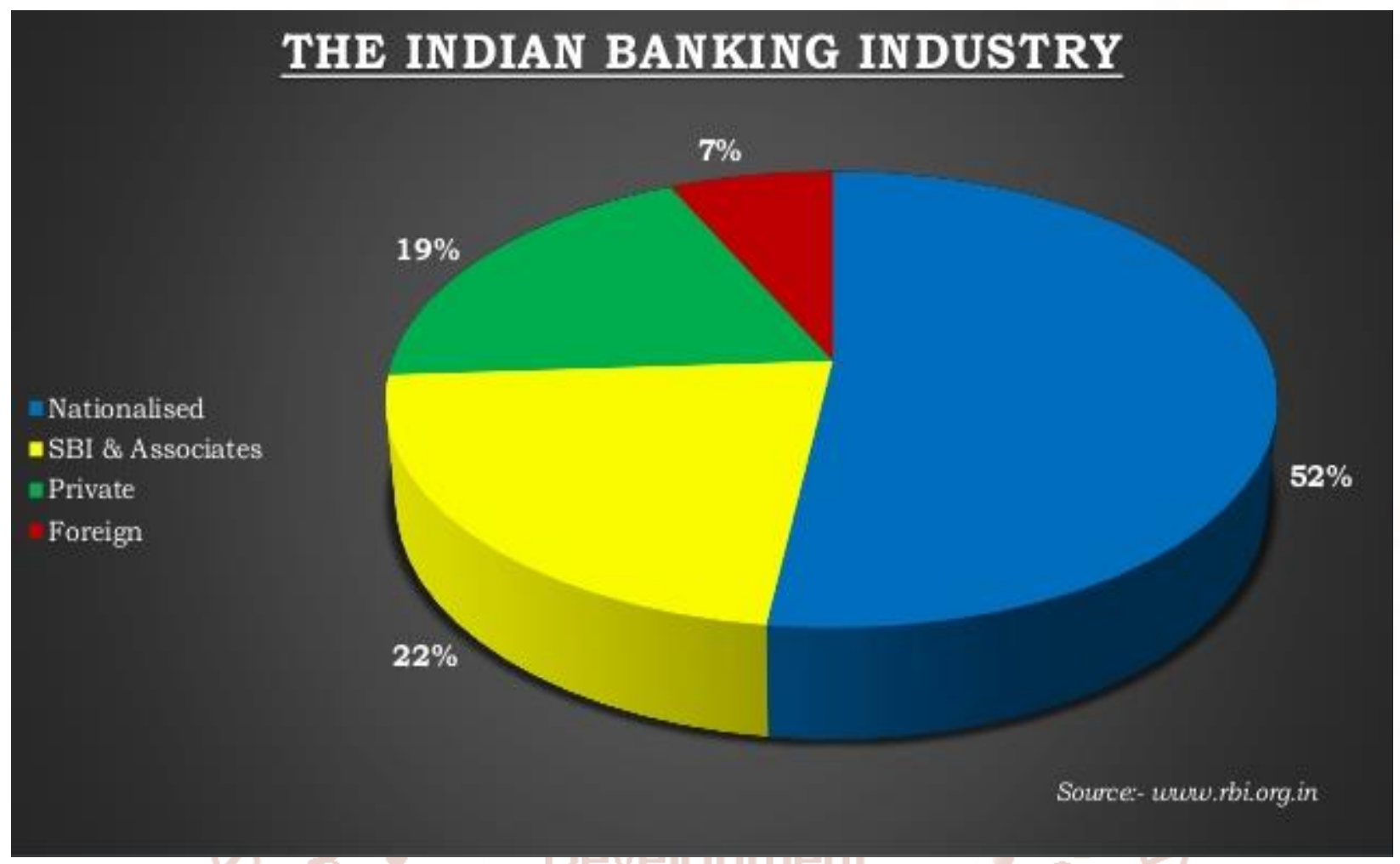

\section{STEPS TAKEN BY NABARD}

- Hundred per cent refinance to Hundred per cent refinance to Banks for loans given to SHGs

- Repayment period of loans by banks to SHGs varies from two to three years

- Repayment period of loans by SHGs to flexible annum

\section{OBJECTVES}

- To know the level of financial literacy

- To make them aware about micro finance

- To know the need of rural people

- To suggest instruments and schemes of financial inclusion

\section{PRESENT STATUS OF MICROFINANCE}

- $31 \%$ (131.1 million) of the total deposit accounts are in rural India

- $43 \%$ (22.4 million) of total credit accounts are in rural India
- Positive impact on the poor (Rohini Pande /Burgess paper

\section{CONCLUSION AND RECOMMENDATIONS}

Despite 70 years as an independent nation, India is still lagging behind in the process of providing financial services to the masses with nearly half the households remaining unbanked, and nearly ninety percent villages not having bank branches. More importantly, people in these unbanked areas do not fully appreciate why they need a bank account at all, or why loans from the formal sector are more useful than the informal sector. The advantages of a financially inclusive model are many-fold. Illustratively, unbanked and underprivileged could receive appropriate and timely payments for social benefit and employment schemes through the Direct Cash Transfer program. The government and Reserve Bank of India have been making concerted efforts since mid1950's and with renewed vigor since 2006 but success has been rather slow, due to lack of a 
strong network, and financial instruments not suited to rural residents. Moreover, lack of awareness and financial literacy among rural population are primarily responsible for low penetration of financial services. All governments' schemes are well thought of and have long lasting impact but implementation of these schemes are still a big problem area which need immediate actions.

\section{REFERENCES}

1. Distribution (2011),"Number of Ration Shops in the country", June. Planning Commission (2009)

2. Financial Inclusion With Reference To Daily Wage Earners", Journal of Business Management \& Social Sciences Research, Volume 2, No. 6, June "Report on Financial Sector Reforms"

3. Financial Inclusion in India: Select Issues Charan Singh RBI Chair Professor Economics \& Social Science Indian Institute of Management Bangalore

4. Kishanjit Badu, Krishan Jindal, "Microfinance Emerging Challenges", TATA McGraw HILL, New Delhi, 2000, P:273-317. 126 Op. Cit., SIDBI Report, P: 173. 127 Meera Lal, "SHGBank Linkage in India: Empowerment and Sustainability", B.R. Publishing Corporation, Delhi, 2007, P: 126-132

5. Kamath, Rajalaxmi (2008) "Ramanagaram Financial Diaries: Loan repayments and cash patterns of the urban slums", IIMB Working paper 268. Ministry of Consumer Affairs, Food and Public Joshi, Deepali P. (2014), "Strategy Adopted For Financial Inclusion", Speech, Workshop of Government of Madhya Pradesh, New Delhi, January. K., Divya (2014), “A Study On Impact Of” (Chairman: Dr. Raghuram G. Rajan). Radcliffe, Dan (2012), "A Digital Pathway to Financial Inclusion", Bill \& Melinda Gates Foundation. RBI (2005), "Report on Rural Credit and micro finance" (Chairman: H.R. Khan)

\section{Government Reports}

1. Economic survey of India 2015-16

2. Union budget 2016-17

3. Economics Times

4. youjna 